\title{
METHODS OF OPTIMIZING THE SPEED AND ACCURACY OF OPTICAL COMPLEX GUIDANCE SYSTEMS BASED ON EQUIVALENCE OF AUTOMATIC CONTROL SYSTEM DOMAIN OF ATTRACTION AND UNCONDITIONAL STABILITY OF THEIR EQUIVALENT CIRCUITS
}

\author{
V.L. Kodkin, kodkinvl@susu.ru, \\ A.A. Baldenkov \\ South Ural State University, Chelyabinsk, Russian Federation
}

\begin{abstract}
The paper covers theoretical analysis of the existence conditions for sliding processes in electromechanical servo systems of optical complexes, based on coefficients of differential equations describing the systems. It is shown that these conditions may be formulated by frequency characteristics of dynamic elements of electromechanical complexes. The conditions of sliding based on servo drive frequency characteristics are obtained, and it is shown that these conditions are equivalent to the conditions of absolute stability of obtained equivalent circuits of servo drives with relay elements. With the help of the designed method the author has made suggestions on the synthesis of near-ideal sliding processes in electromechanical complexes described by high-order differential equations. The author assumes that sliding processes may be realized in electromechanical systems with asynchronous drives as well; the data of experiments proving these assumptions are given.

Keywords: electromechanical systems, variable-structure systems, sliding processes, absolute stability, frequency characteristics.
\end{abstract}

\section{Introduction}

Most optical surveillance complexes use controlled platforms. A bright example is 6-axis motion hexapod platforms able to move along a very complicated trajectory. It is essential that these devices be supplemented with servo drives having excellent dynamic characteristics. For example, servo drives of Physik Instrumente hexapods (Germany, USA) have a bandwidth of $25 \mathrm{~Hz}$ for the amplitude of $0.1 \mathrm{deg}$. and $3.3 \mathrm{~Hz}$ for the amplitude of $4 \mathrm{deg}$. The construction of these hexapods includes direct current drives with PI controllers. Dimension and weight characteristics of these drives are not very good; and these drives are also sensitive to external disturbances and overloads. PI controllers cannot be considered the optimal means for obtaining high dynamic characteristics of automatic control systems (ACS).

It should be noted that the theory of sliding processes in variable-structure systems (SP in VSS) as well as the theory of attraction has not found a wide application in the modern control systems. There are many reasons for that; in particular, it is difficult to apply methods of the theory of SP in VSS and theory of attraction for the systems with non-linear, non-stationary elements, high-order elements, time delays etc. [1]. At the same time, the conditions of stability have been developed in practice for the systems of any complexity the character of which is not always clear. The analysis typically requires only experimental data on the object, for example, its frequency characteristics. In this respect, there have been many attempts to find the correlation between the conditions of stability and attraction. While the conditions of stability associated with the condition of attraction were obtained some time ago [2], it has still been impossible to obtain the conditions of attraction associated with the conditions of stability and to apply them for SP synthesis in electromechanical systems (EMS), even at the cost of accuracy.

\section{Problem statement}

Thus, let the EMS with sliding (the circuit is presented in Fig. 1) be described by the equation:

$$
\left\{\begin{array}{c}
T^{2} \ddot{x}+K|x| \text { sign } S=0 ; \\
S=T_{1} \dot{x}+x .
\end{array}\right.
$$




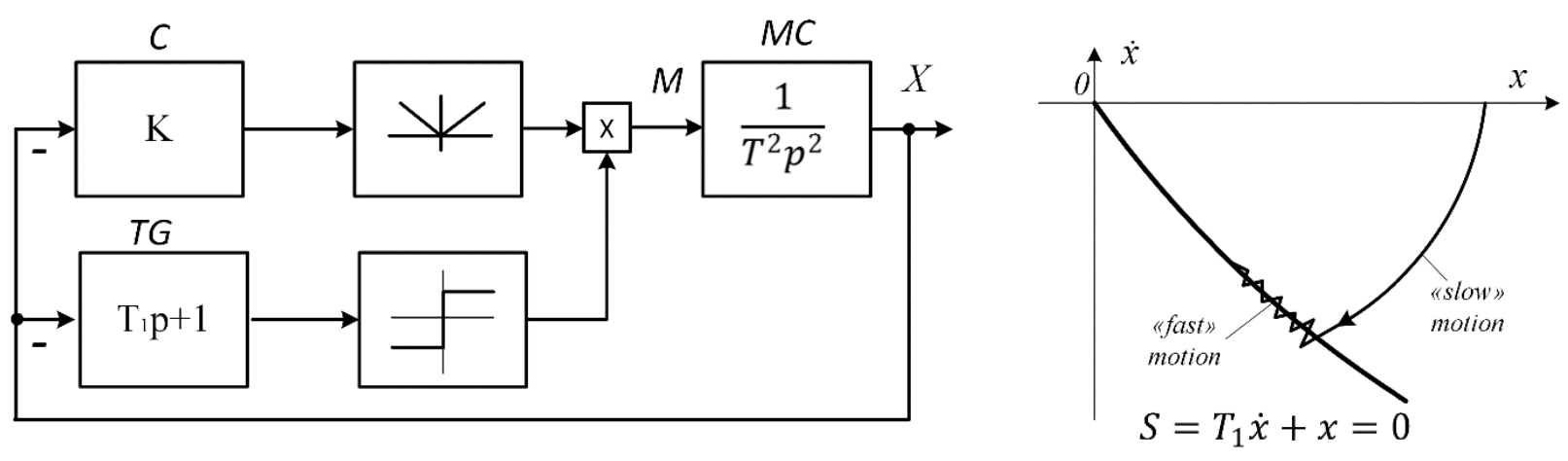

Fig. 1

The control is based on the following: the conditions of opposing motions are created in the certain area of the phase space around the surface $S=0$. The phase trajectory is "resolved" into two motions: fast and slow. These motions are stable enough against external disturbances and changes in the system parameters. These conditions are found as follows: at $S=T_{1} \dot{x}+x=0$, due to ACS equation (1) the following conditions should be met:

$$
\begin{aligned}
& \dot{s}>0, \text { at } s<0 \text { and } \operatorname{sign}(s)=-1 ; \\
& \dot{s}=T_{1} \ddot{x}+\dot{x}=T_{1}\left(-\frac{k x \cdot \operatorname{sign}(s)}{T^{2}}\right)+\dot{x}=\frac{k x T_{1}}{T^{2}}-\frac{x}{T_{1}} \geq 0 ; \\
& \text { at } x>0, \frac{k T_{1}}{T^{2}}-\frac{1}{T_{1}} \geq 0 ; \quad T_{1} \geq \sqrt{\frac{T^{2}}{k}} .
\end{aligned}
$$

The final condition links transfer functions of the controlled member $\left(\frac{1}{T^{2} p^{2}}\right)$, switch trajectory generator $\left(T_{1} p+1\right)$, and controller coefficient $K$.

Along with that, the element with cutoff frequency $\omega=\sqrt{\frac{K}{T^{2}}}$ is a controlled member engaged in the feedback with controller with $K$ coefficient.

Thus, in the system (1) there will be an ideal sliding process around $S=0$ under the fulfilled conditions (2) which may be described as follows:

Time constant of the sliding trajectory generator (or attractor) should be larger than time constant of the circuit formed by the controlled member element and controller-element.

In servo drives it is necessary to distinguish structure elements which have the greatest influence of the dynamics. These are controller, actuating motor, and reduction gear. Ideally, the motor, reduction gear, and mechanism may be described by the eleventh-order differential equation, and all the system may be described by the equations (1). Most frequently, the drive is not "ideal", so its system of equations is a system of high-order nonlinear equations, and the conditions of sliding are a system of inequalities with multiple poorly determined parameters and coefficients which can hardly be transferred to the engineer-understandable language. Probably, the lack of universal engineering methods of SM calculation for VSS prevented their widespread introduction into servo drives and was the reason for return to linear controllers, particularly to PI controllers. The above stated, thus, sets the problem of development of engineering criteria of the conditions of sliding in real servo drives.

To develop engineering criteria it is necessary to find a condition which would use "engineering" characteristics of the controlled member and would be more universal than the conditions of attraction. Today, such a universal condition which suits practically all technical objects is the condition of ACS stability.

It is essential for EMS of optical complexes. On the one hand, such systems use the mechanical elements of high quality; on the other hand, these systems impose strict requirements to dynamics which still do not prevent non-idealities, and, along with that, "real" fast motions should be avoided because "bounce" around the motion trajectory of optical systems is impermissible. 


\section{Methods}

The condition (2) may be "transferred" to the frequency characteristics of EMS elements as follows:

The condition of ideal sliding is met when two elements - the sliding trajectory generator and the circuit formed by the controller and controlled member - are connected in series with equivalent phase characteristic of $-90^{\circ}$ minimum, and the value of $-90^{\circ}$ is reached at $\omega \rightarrow \infty$ (1).

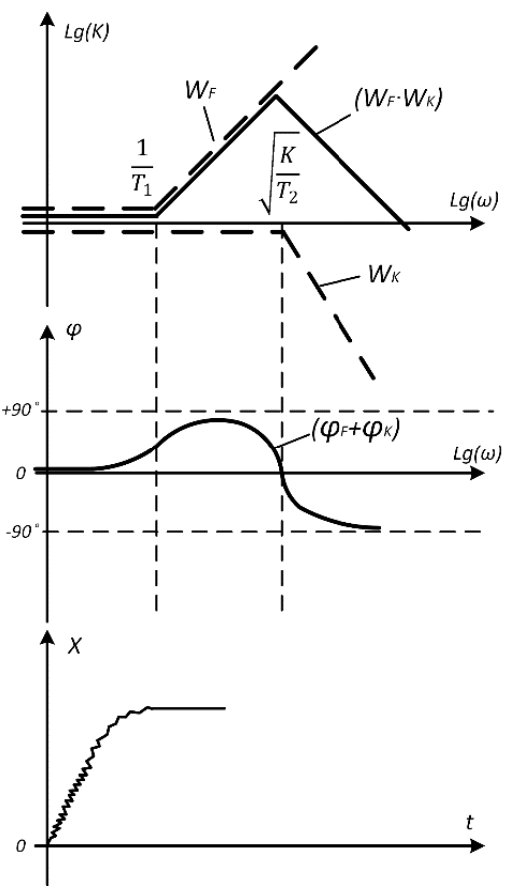

a)

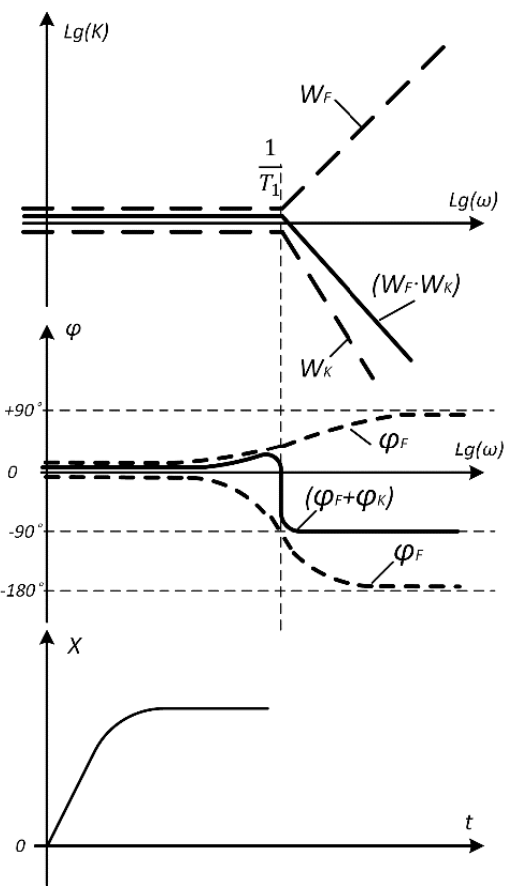

b)

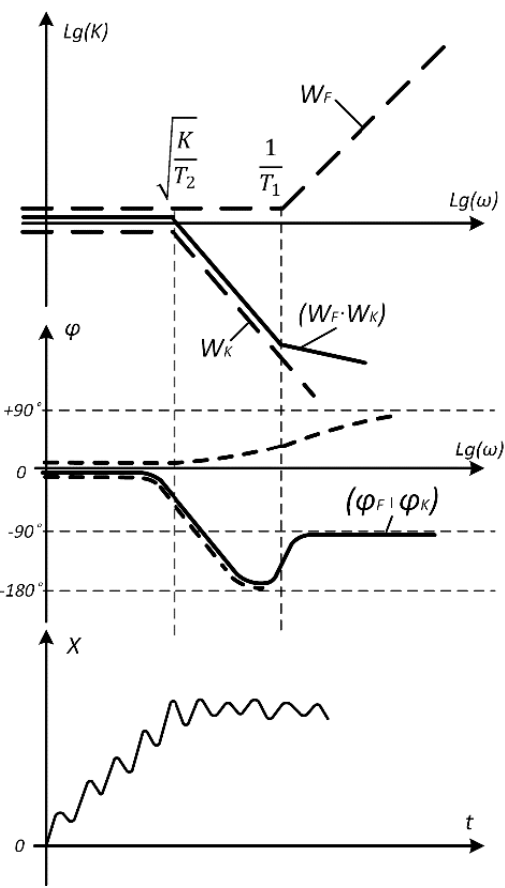

c)

Fig. 2

Fig. 2 shows the direct correlation between the condition (2) and this assumption.

- Ideal sliding - the condition (2) is met, equivalent phase shifts of elements $\left(W_{F}\right)$ and circuit $\left(W_{\mathrm{K}}\right)$ is $-90^{\circ}$ minimum, frequency characteristics are presented in Fig. 2 a.

- Critical sliding - phase shift $-90^{\circ}$ at the frequency - boundary state of stability for the diagram is presented in Fig. 3, frequency characteristics are shown in Fig. 2b.

- Real sliding (with rupture zones), due to characteristics of the member the phase shift reaches the value of $-90^{\circ}$ at end frequency which determines the parameters of fast motions - Fig. 2c. The suggested frequency condition is met if the real part of frequency characteristics under consideration transferred to the complex space is positive:

$\operatorname{Re}\left(W_{\mathrm{\kappa}} \cdot W_{F}\right)>0$.

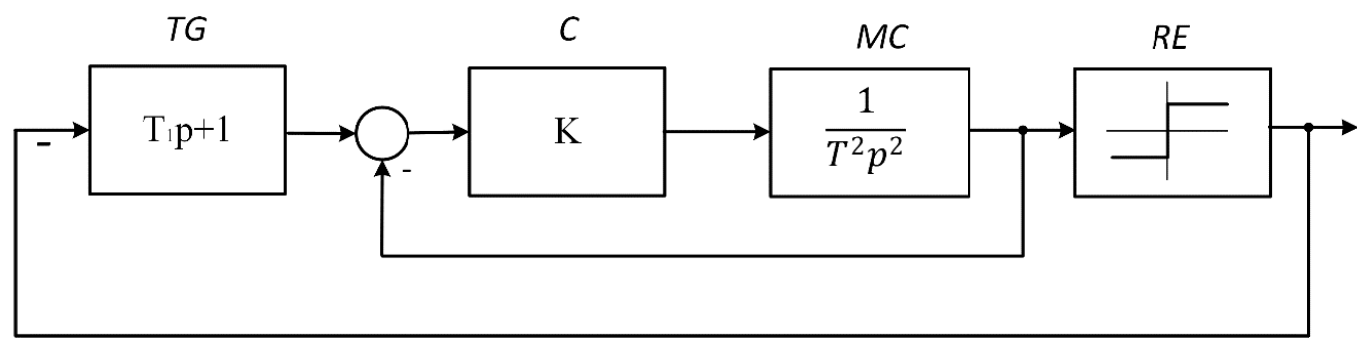

Fig. 3

This condition is special case of the absolute stability [4] of equivalent circuit presented in Fig. 3.

Let us assume that the condition of stability (3) corresponding to the conditions of ideal sliding (2), i.e. the existence of ideal conditions of attraction, is preserved in any system with frequency characteristics that meet the condition (3). Then, applying the Popov criterion [3] we can obtain a convenient inter- 


\section{Управление в технических системах}

pretation of different variants of sliding modes which is very important for the practical use of SM in EMS.

In the variable structure control systems with the general controlled member (Fig. 4) there will be sliding mode if for its equivalent circuit (Fig. 5) the condition of absolute stability will be met [3], and at $q=0$ the sliding will be near-ideal regardless of the nature of controlled member, i.e. the condition of stability for the equivalent circuit is equivalent to the condition of sliding for initial circuit (Condition 2).

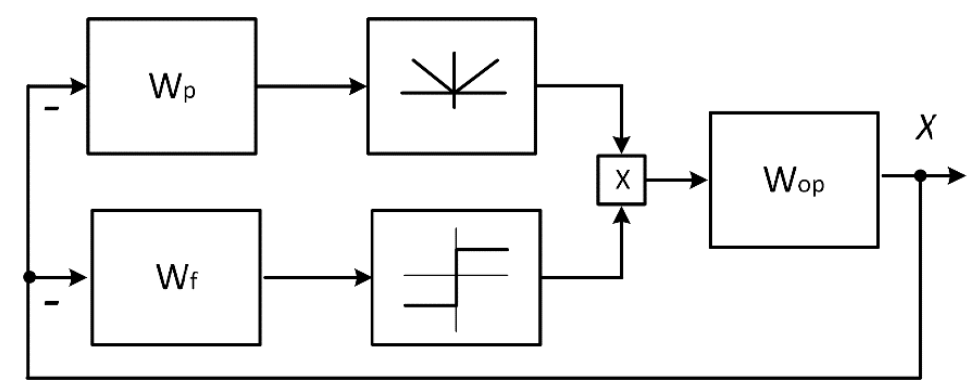

Fig. 4

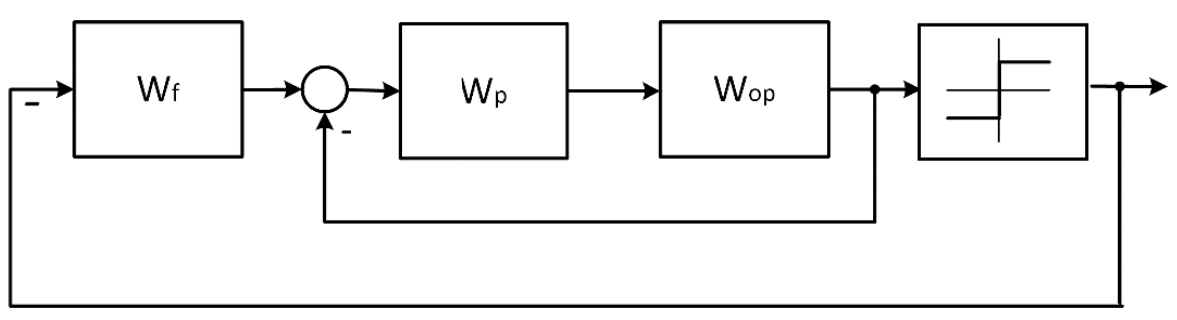

Fig. 5

(In one of his first notable works dedicated to VSS, Emelyanov [5] describes the existence condition for sliding in high-order systems $(n)$ and also the order of surface and controller $(n-1)$. The condition links the coefficients of three elements - controlled member, switch generator, and controller (chapter III $\S 3$ [5]). If this condition is "converted" to transfer functions and frequency characteristics of the stated dynamic elements, the result will be the condition equivalent to restriction of phase shift of elements connected in series - sliding trajectory generator and circuit formed by the controlled member and controller absolutely matching the condition (2) presented in this paper or the condition of stability of equivalent circuit. Appendix 1 provides proof of this statement, which, in author's opinion, captures the qualitative essence of the suggested methods of ACS synthesis.

In order to evaluate the existence of sliding in the initial system (1) the criterion of stability in the system (3) may be used in analysis of SM in the system with almost any nonlinear object, i.e. any object falling under the theory of absolute stability, thus excluding a detailed analysis of each particular case, as it is implemented in the theory of SM in VSS.

It should be noted that fulfillment of the conditions (2) which does not depend on the controller coefficients if the conditions (3) are met makes it possible to introduce a concept of "EMS structural stability" for EMS; this stability is not disturbed when controller coefficients vary. Considering that in real EMS it is difficult to accurately determine the set of essential parameters the suggested concepts and conditions are of great practical importance.

\section{Results and recommendations}

Let us consider the problem of synthesis of sliding processes in the real servo drive. There are three possible variants of solution.

The first variant is to design such elements that make the system near-ideal, but this way is normally very expensive.

The second variant is to develop a complex multidimensional controller in accordance with theory of VSS. This task is very difficult and almost unsolvable.

The third variant involves the method suggested in this paper which means to find a controller pro- 
viding the absolute stability of equivalent circuit presented in Fig. 7. The possible solution is crosscoupling with $\alpha$ and $\beta$ coefficients shown in Fig. 6 and Fig. 7.

Fig. 9 presents frequency-response characteristics of ACS. All conditions of equivalent circuit stability (Fig. 7), frequency conditions (3), and conditions of forced sliding (condition (2)) for the initial circuit (Fig. 6) are met. Using this method in servo drive resulted in introduction of correcting feedback by the speed of actuating motor which increased the dynamics of $400 \mathrm{~W}$ servo drive from 1 to $5 \mathrm{~Hz}$ (process presented in Fig. 8).

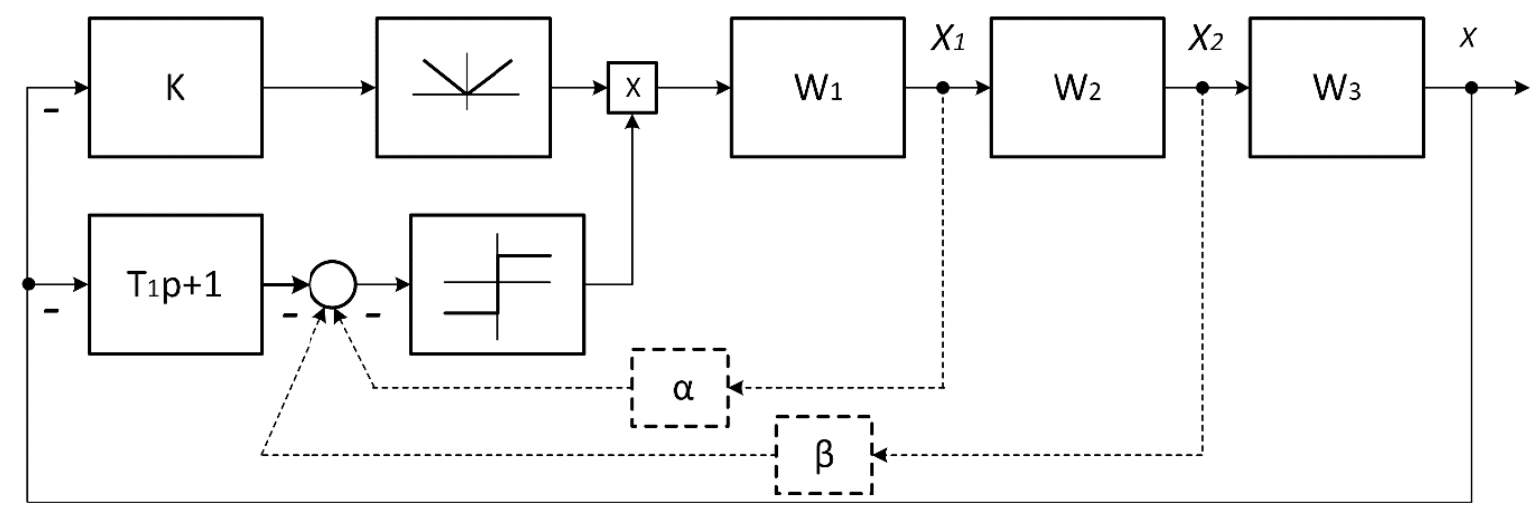

Fig. 6

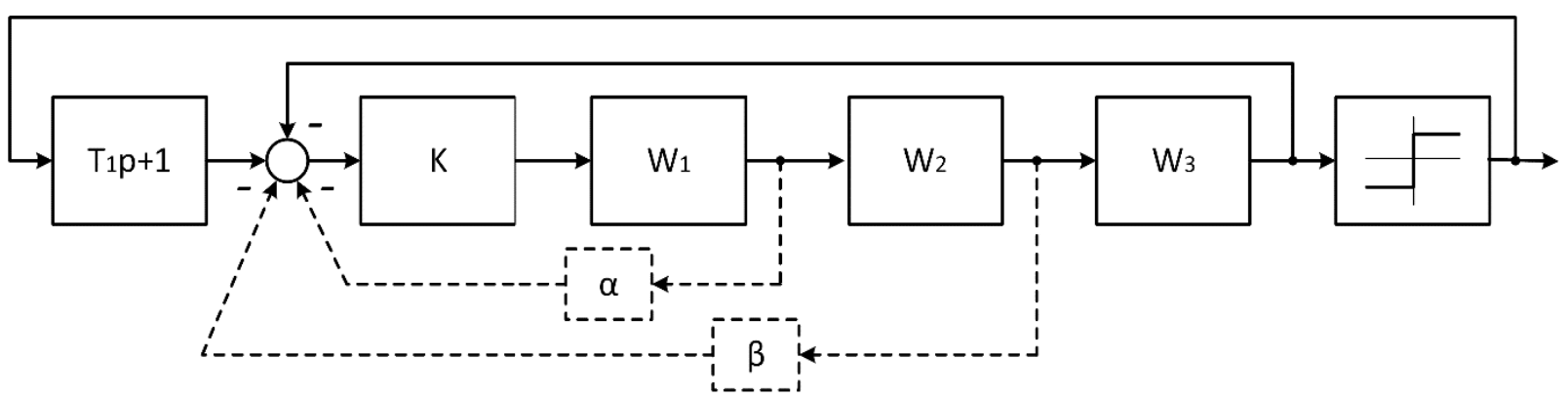

Fig. 7

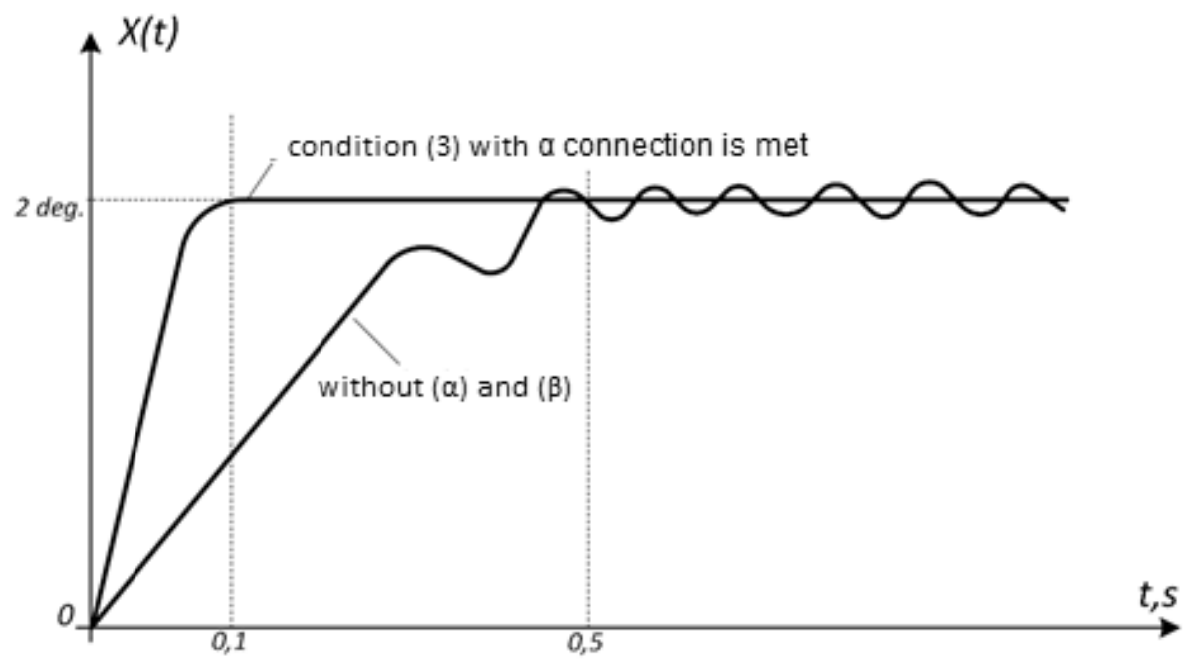

Fig. 8

A subject of practical interest is correcting the frequency characteristics of alternating current drives, particularly asynchronous drives, by dynamic positive stator current feedback.

(Appendix 2 contains the qualitative analysis and construction of non-linear frequency characteristic of alternating current motor - asynchronous, in particular. The same Appendix gives the explanation 


\section{Управление в технических системах}

why traditional control methods for such motors - i.e. vector control and direct torque control - are not effective for servo drives subjected to nondeterministic torque loads).

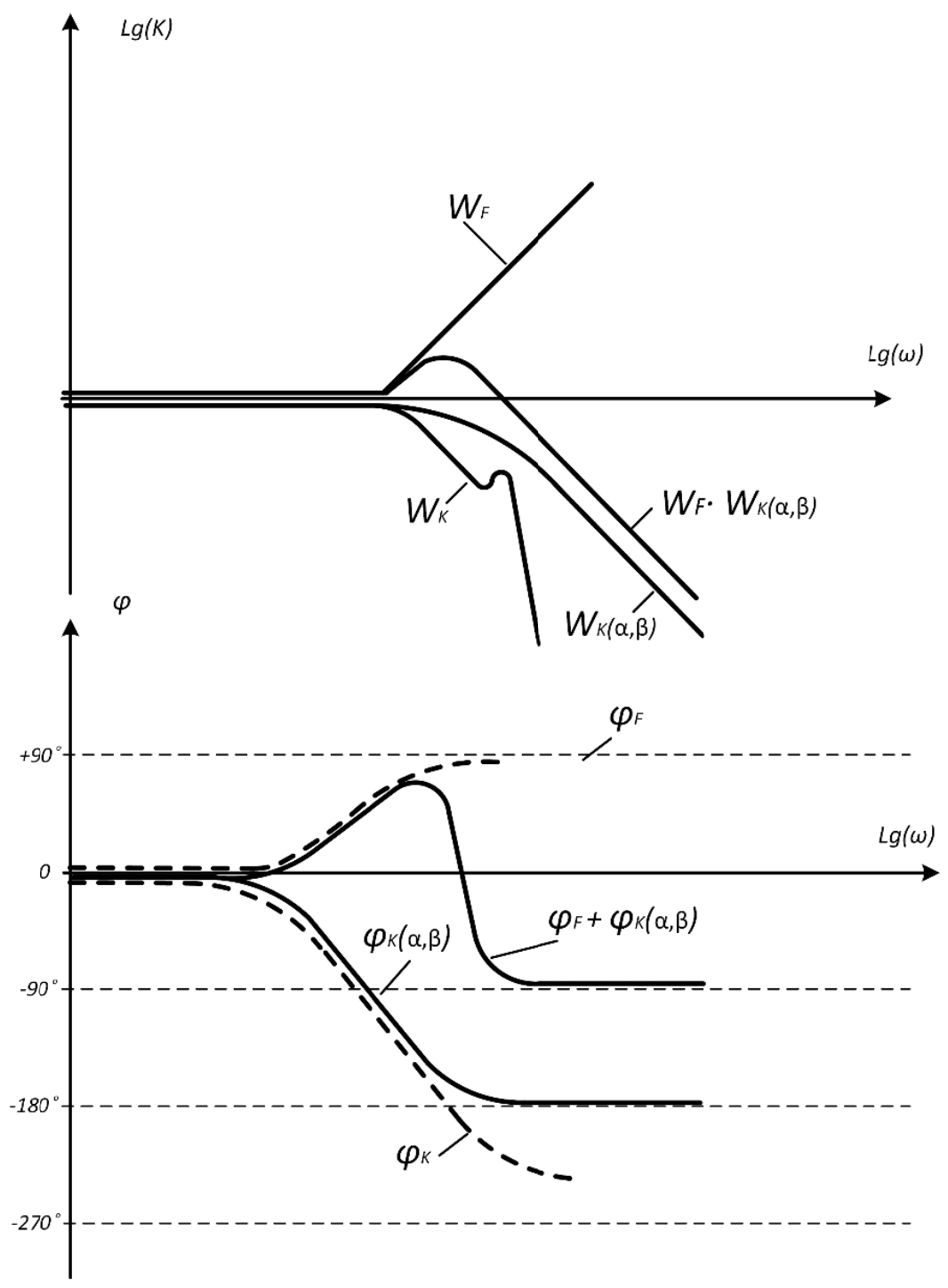

Fig. 9

Fig. 10 presents a function chart of frequency-controlled asynchronous drive (FT-AD, D) where positive stator current feedback with a special dynamic correction $\mathrm{W}$ "corrects" the frequency characteristic of the drive so it is possible to implement the sliding mode with variable structure controller (VSC).There were conducted the experiments with 4 possible variants of drive correction - open vector and scalar control circuits, drive with speed closed loop, and drive with positive stator current feedback. The drives were subjected to static load (Fig. 11, Table 1),speed-setting harmonic signals (Fig. 12, Table 2), and harmonic moment disturbances (Fig. 13, Table 3). In all cases the process were optimized, i.e. it was possible to obtained the best results for the given structure. In all experiments the best results were observed for systems with positive current feedback. The special attention should be focused on counteraction to moment loads and on correction of phase shift of speed error signals.

The suggested structure linearization of positive stator current feedback made it possible to significantly "improve" the dynamic characteristics of asynchronous drive - in particular, to decrease the phase shift of speed signal from the load-controlling signal by 30 electric degrees in comparison with the speed closed loop circuit. Along with that, the amplitude of angular oscillations of $370 \mathrm{~W}$ asynchronous drive was $30-40^{\circ}$ at a frequency of $1.5 \mathrm{~Hz}$. 


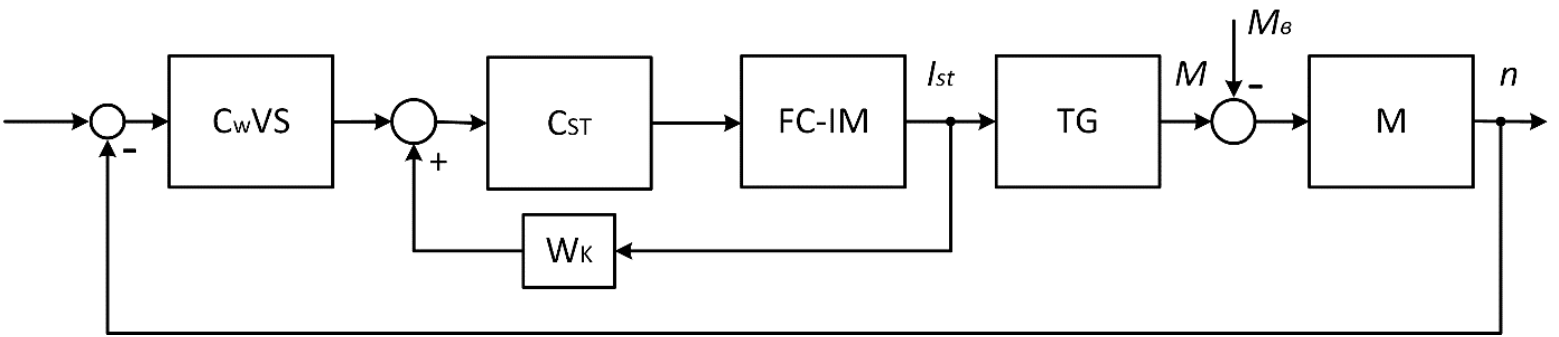

Fig. 10

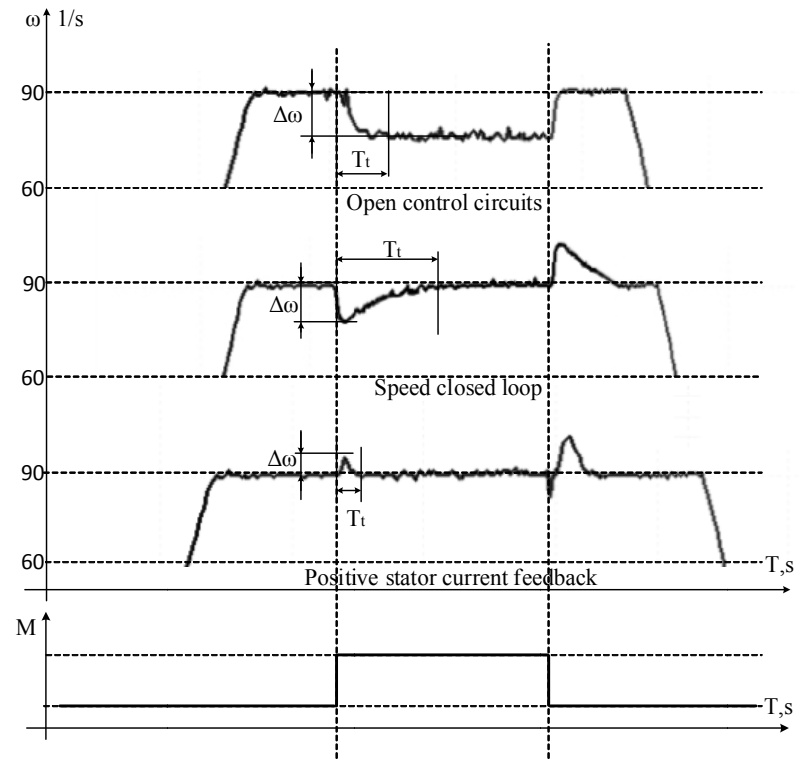

Fig. 11

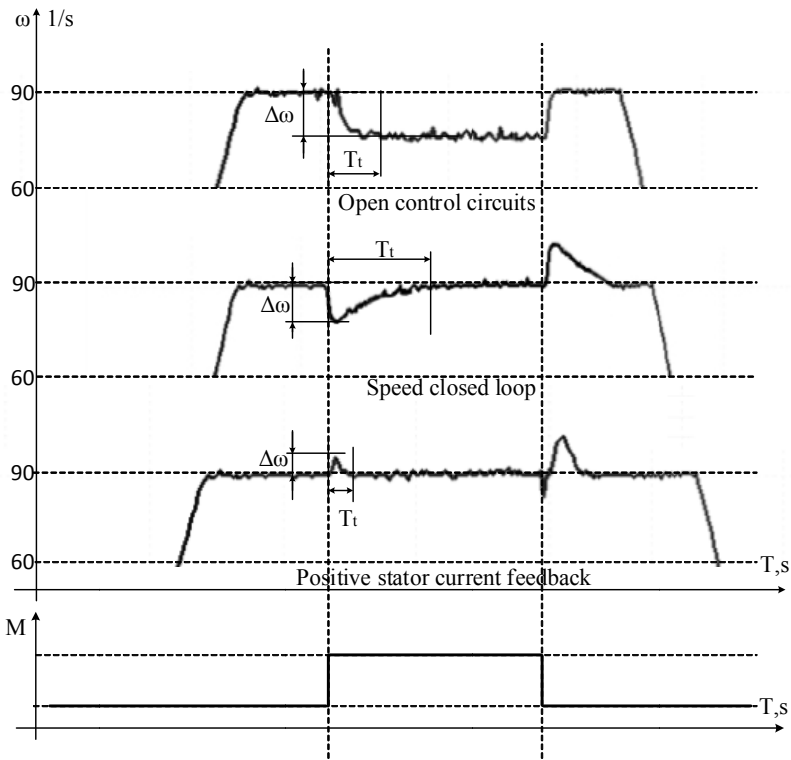

Fig. 12

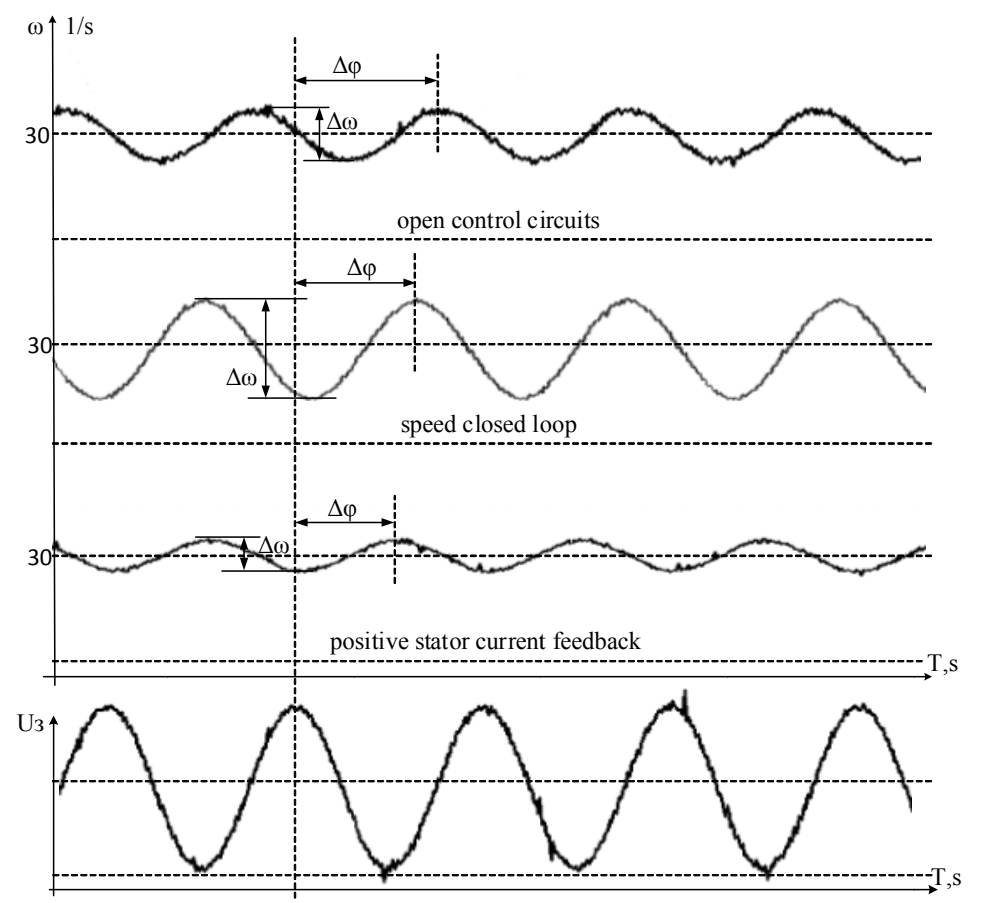

Table 1

\begin{tabular}{|l|c|c|}
\hline & $\Delta \omega, \mathrm{s}^{-1}$ & $\mathrm{Tt}, \mathrm{s}$ \\
\hline Open control circuits & 10 & 0,3 \\
\hline Speed closed loop & 10 & 0,6 \\
\hline $\begin{array}{l}\text { Positive stator current } \\
\text { feedback }\end{array}$ & 4 & 0,1 \\
\hline
\end{tabular}

Table 2

\begin{tabular}{|l|c|c|}
\hline & $\Delta \omega, \mathrm{s}^{-1}$ & $\Delta \varphi$, el.deg. \\
\hline Open control circuits & $\pm 5,03$ & 84 \\
\hline Speed closed loop & $\pm 4,99$ & 84 \\
\hline $\begin{array}{l}\text { Positive stator current } \\
\text { feedback }\end{array}$ & $\pm 6,4$ & 72 \\
\hline
\end{tabular}

Table 3

\begin{tabular}{|l|c|c|}
\hline & $\Delta \omega, \mathrm{s}^{-1}$ & $\Delta \varphi$, el.deg. \\
\hline Open control circuits & $\pm 2,19$ & 270 \\
\hline Speed closed loop & $\pm 3,31$ & 230 \\
\hline $\begin{array}{l}\text { Positive stator current } \\
\text { feedback }\end{array}$ & $\pm 1,19$ & 200 \\
\hline
\end{tabular}

Fig. 13 


\section{Управление в технических системах}

\section{Conclusion}

According to preliminary estimates, such drives may be used in high-accuracy optical platforms, for example, hexapods. The experiments show that the drive with dynamic correction has a frequency characteristic close to the one necessary for effective functioning as a component of the servo drive with sliding modes, and, consequently, with high dynamic characteristics.

\section{References}

1. Emelyanov S.V., Korovin S.K. Novye tipy obratnoy svyazi: Upravlenie pri neopredelennosti [New Types of Feedback: Indefiniteness-Related Control]. Moscow, Nauka. Fizmatlit, 1997. 352 p.

2. Rouche N., Habets P., Laloy M. Stability Theory by Lyapunov's Direct Method. SpringerVerlag, NewYork, Heldelberg \& Berlin, 1977.

3. Kodkin V.L. [Optimality and Stability Electromechanical Systems]. Proc. VIII International Scientific Conference. North Charleston, SC, USA: Create Space, 2015, pp. 136-143. (in Russ.)

4. Popov V.M. Hyperstability of Control System. Springer-Verlag, NewYork \& Heldelberg Berlin, 1973.

5. Emelyanov S.V Teoriya sistem s peremennoy strukturoy [Theory of Variable-Structure Systems]. Moscow, Nauka Publ., 1970. 592 p.

\section{Appendix 1}

Let us consider the initial circuit and equivalent. As follows from the stability of the latter, there exists Lyapunov function which is of positive terms for the whole state space in virtue of equations (structure) of the system, and along with that the time derivative of this function is of negative terms for the same space.

Let us assume that this function is the quadratic form relative to the switch surface $S$, as $S$ function reverses its sign passing over the zero value. To meet the condition of stability, $S$ and $\dot{S}$ should have different signs in all the space.

$L \approx S^{2} ; L^{\prime}=2 S \cdot \dot{S} ; L>0, L$ should be less than zero, which means that $S$ and $\dot{S}$ should have different signs.

For the equivalent circuit (Fig. 5)

$S=U \cdot \frac{W_{1} \cdot W_{2} \cdot K}{1+K W_{1}}$

$U$ is a relay element output $\pm U_{m}$ and reverses its sign when $S$ reverses.

Having found the time derivative of $\mathrm{S}$ function

$\dot{S}=\frac{W_{1} W_{2} K U}{1+K W_{1}} p-S(0)$.

We will assume that $\mathrm{KW}>>1$, then:

$\dot{S} \approx W_{2} \cdot p \cdot U-S(0)$.

As $U$ signal switches at the surface $S=0 ; S(0)=0$ and $\dot{S} \approx W_{2} \cdot p \cdot U$.

At $S<0, U=-U_{m}, \dot{S}$ should be larger than zero according to the condition of stability. Consequently:

$\dot{S} \approx W_{2} \cdot p \cdot\left(-U_{m}\right)>0, a\left(W_{2} p\right)<0$.

For the variable structure system (Fig. 4):

$S=\frac{W_{1} \cdot W_{2} \cdot K}{1+K W_{1} \cdot \operatorname{sign} S}$

considering the domain around $S=0$, the part of the space where $S<0$, in this domain the feedback becomes positive and

$$
S=\frac{K \cdot W_{1} \cdot W_{2}}{1-K W_{1}}
$$

from the same conditions as for the equivalent circuit, let us assume that $K W_{1}>>1$ and $S=-W_{2}$, then $\dot{S}$ in the positive feedback circuit $\dot{\mathrm{S}}=-W_{2} p-S(0) \approx-W_{2} p$ and according to the condition of stability of the equivalent circuit, we shall obtain $\dot{S}>0$.

As in our reasoning we do not limit transfer functions $W_{1}, W_{2}, K$, we can consider the condition to be true for all the elements for which transformation is true, i.e. for almost all EMS elements. 


\section{Appendix 2}

To obtain the frequency characteristic for alternating current drive, particularly asynchronous frequency-controlled drive, let us consider this drive to be the equivalent circuit with modulation elements - Fig. A2.1.

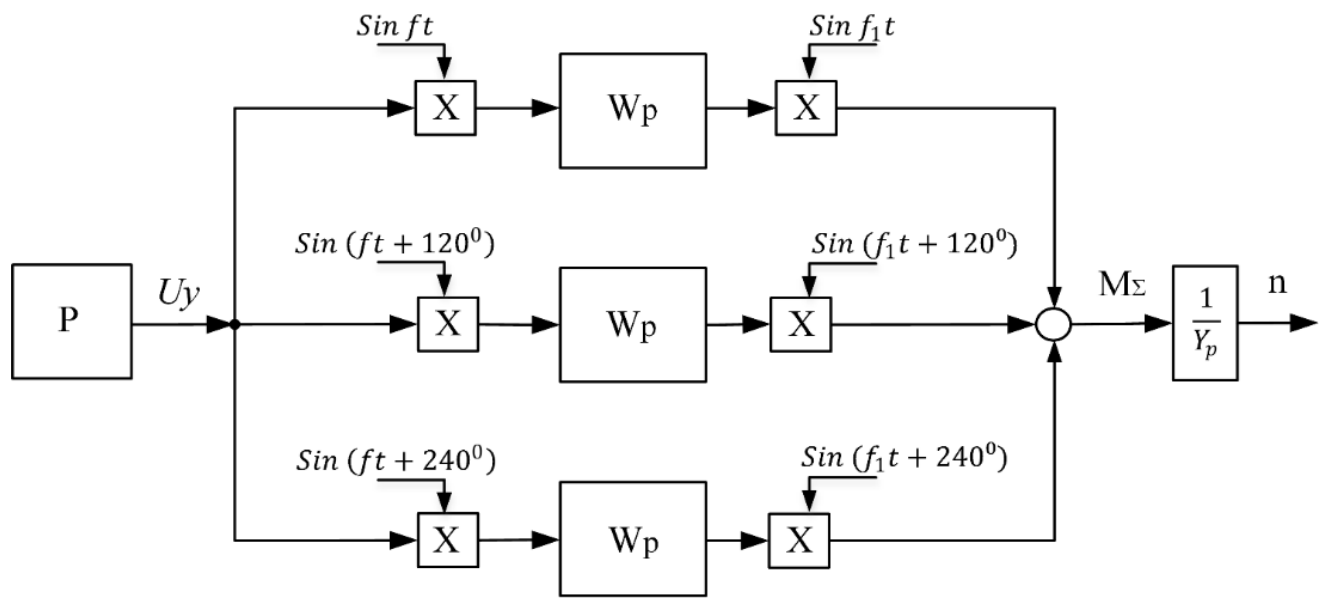

Fig. A2.1

Frequency $f$ is a frequency of stator voltage, and, considering rotor lag, the rotor speed. For the "frozen" frequency the transfer function is the following:

$W_{1 \text { equiv }}=\frac{3}{2} \operatorname{Re} W(p+j f)$, where $f_{1}=f$ in synchronous motors;

$W_{\text {2equiv }}=\frac{3}{2} \operatorname{Re} W(p+j f) \cdot \Delta W(p+j \Delta S)$, where $f_{1}=f-\Delta S$ in induction motors.

The obtained transfer function is non-linear and depends on $f$, i.e. the dynamics of synchronous and asynchronous drives differs for different speed (Fig. A2.2, A2.3). Now such drives are usually provided with vector control and reverse torque control. Non-linear in thee circuits are compensated with other, non-linear, reverse operations. Such operation is in a large error, especially for servo drives with a complex spectrum of errors and moment disturbances - for example, for drives of optical complexes. Along with that, the inevitable deviations of model of compensating non-linearity and real non-linearity the circuit "falls apart". The suggested correction using positive feedback is more effective and suitable for servo drives, according to the experimental data presented in the paper.

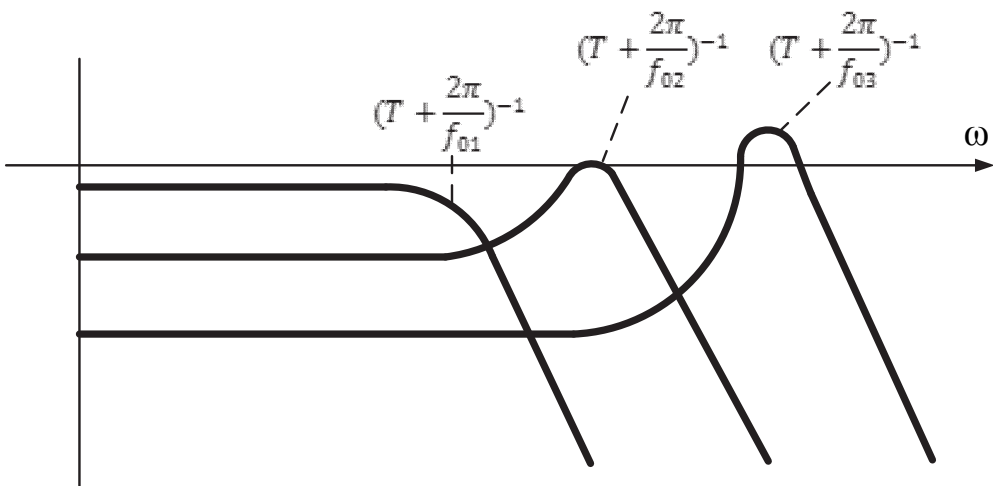

Fig. A2.2

Frequency response of the synchronous drive

$$
\text { at } W=\frac{1}{1+T p} \text { and } f=f_{1}=\left\{\begin{array}{l}
f_{01} \\
f_{02} \\
f_{03}
\end{array}\right. \text {. }
$$



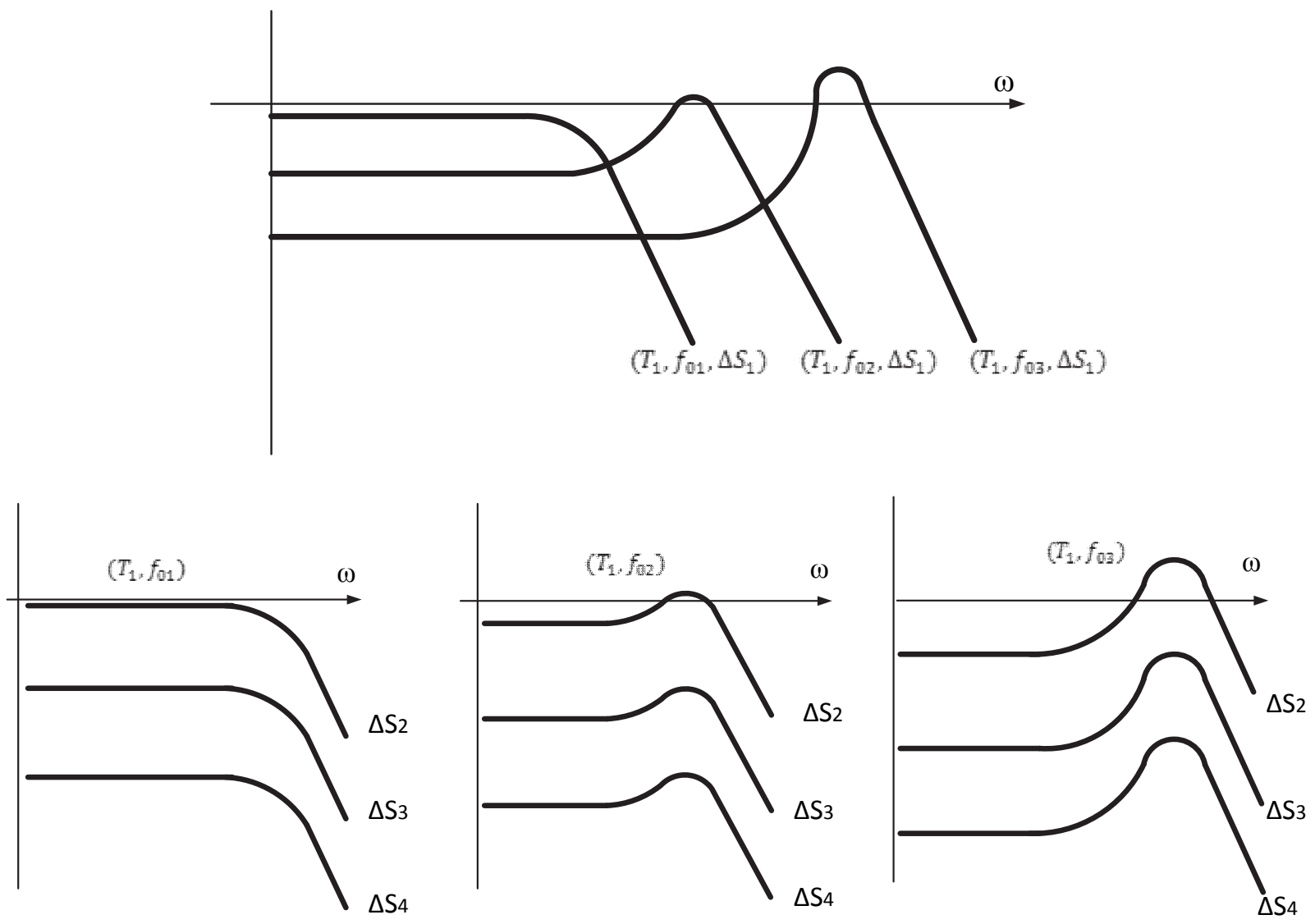

Fig. A2.3

Multidimensional family of frequency response of induction drive

at $W=\frac{1}{1+T p}$ and $f=f_{1}-\Delta S=\left\{\begin{aligned} & f_{01}-\left\{\begin{array}{l}\Delta S_{1} \\ \Delta S_{2} \\ \Delta S_{3}\end{array}\right. \\ & f_{02}-\left\{\begin{array}{l}\Delta S_{1} \\ \Delta S_{2} \\ \Delta S_{3}\end{array}\right. \\ & f_{03}-\left\{\begin{array}{l}\Delta S_{1} \\ \Delta S_{2} \\ \Delta S_{3}\end{array}\right.\end{aligned}\right.$

Received 11 October 2016 


\title{
МЕТОДЫ ОПТИМИЗАЦИИ БЫСТРОДЕЙСТВИЯ И ТОЧНОСТИ СИСТЕМ НАВЕДЕНИЯ ОПТИЧЕСКИХ КОМПЛЕКСОВ НА ОСНОВЕ УСЛОВИЯ ЭКВИВАЛЕНТНОСТИ ОБЛАСТИ ПРИТЯЖЕНИЯ САР И АБСОЛЮТНОЙ УСТОЙЧИВОСТИ ИХ СХЕМ ЗАМЕЩЕНИЯ
}

\author{
В.Л. Кодкин, А.А. Балденков \\ Южно-Уральский государственный университет, г. Челябинск
}

\begin{abstract}
Приводятся результаты теоретического анализа условий существования скользящих процессов в следящих электромеханических системах оптических комплексов по коэффициентам дифференциальных уравнений, описывающих системы. Показано, что эти условия могут быть сформулированы по частотным характеристикам динамических звеньев электромеханических комплексов. Получены условия скольжения по частотным характеристикам электроприводов и показано, что эти условия эквивалентны условиям абсолютной устойчивости схем замещения электроприводов с релейными элементами. С помощью предложенной методики разработаны предложения по синтезу скользящих процессов, близких к идеальным, в электромеханических комплексах, описываемых дифференциальными уравнениями высокого порядка. Высказано предположение, что скользящие процессы могут быть реализованы и в электромеханических системах с асинхронными электроприводами, приводятся данные экспериментов, подтверждающих эти предположения.

Ключевые слова: электромеханические системы, системы с переменной структурой, скользящие прочессы, абсолютная устойчивость, частотные характеристики.
\end{abstract}

\section{Jumepamypa}

1. Емельянов, С.В. Новые типь обратной связи: Управление при неопределенности / С.В. Емельянов, С.К. Коровин. - М.: Наука. Физматлит, 1997. - 352 с.

2. Руш, Н. Прямой метод Ляпунова в теории устойчивости / Н. Руш, П. Абетс, М. Лалуа. M.: Мup, 1980. -300 c.

3. Кодкин, В.Л. Оптимальность и устойчивость электромеханических систем / В.Л. Кодкин // «Приоритеты мировой науки: эксперимент и научная дискуссия»: материаль VIII междунар. науч. конф. 17-18 июня 2015 г. - Ч. 1. Eстественные и технические науки. - North Charleston, SC, USA: Create Space, 2015. - C. 136-143.

4. Гиперустойчивость автоматических систем / В.М. Попов. - М.: Наука, 1970. 453 c.

5. Емельянов, С.В. Теория систем с переменной структурой / С.В. Емельянов. - М.: Наука, 1970. -592 c.

Кодкин Владимир Львович, д-р техн. наук, профессор кафедры электропривода и автоматизации промышленных установок, Южно-Уральский государственный университет, г. Челябинск; kodkinvl@susu.ru.

Балденков Александр Александрович, аспирант кафедры электропривода и автоматизации промышленных установок, Южно-Уральский государственный университет, г. Челябинск.

Поступила в редакцию 11 октября 2016 г.

\section{ОБРАЗЕЦ ЦИТИРОВАНИЯ}

Kodkin V.L., Baldenkov A.A. Methods of Optimizing the Speed and Accuracy of Optical Complex Guidance Systems Based on Equivalence of Automatic Control System Domain of Attraction and Unconditional Stability of Their Equivalent Circuits / V.L. Kodkin, A.A. Baldenkov // Вестник ЮУрГУ. Серия «Компьютерные технологии, управление, радиоэлектроника». - 2017. T. 17, № 1. - C. 23-33. DOI: 10.14529/ctcr170103

\section{FOR CITATION}

Kodkin V.L., Baldenkov A.A. Methods of Optimizing the Speed and Accuracy of Optical Complex Guidance Systems Based on Equivalence of Automatic Control System Domain of Attraction and Unconditional Stability of Their Equivalent Circuits. Bulletin of the South Ural State University. Ser. Computer Technologies, Automatic Control, Radio Electronics, 2017, vol. 17, no. 1, pp. 23-33. DOI: $10.14529 /$ ctcr170103 